\title{
Benda Cagar Budaya Dan Situs: Sebuah Tinjauan Yuridis
}

\section{Dendi Eka Hartanto S.}

Keywords: regulation, law, cultural resource management, critics, conservation

\section{How to Cite:}

Hartanto S., D. E. (1997). Benda Cagar Budaya Dan Situs: Sebuah Tinjauan Yuridis. Berkala Arkeologi, 17(1), 33-37. https:// doi.org/10.30883/jba.v17i1.767

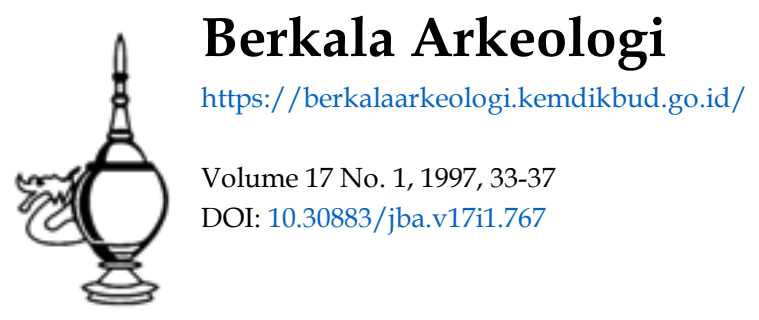

\section{(c) (i) (3)}

This work is licensed under a Creative Commons Attribution-NonCommercial-ShareAlike 4.0 International License. 


\section{BENDA CAGAR BUDAYA DAN SITUS SEBUAH TINJAUAN YURIDIS}

\section{Dendi Ekg Hartanto S. (Suaka Peninggalan Sejarah dan Purbakala D.I. Yogyakarta)}

Sebuah fakta yuridis yang cukup mengkhawatirkan terjadi setelah Undang-Undang Republik Indonesia Nomor 5 Tahun 1992 tentang Benda Cagar Budaya diundangkan pada tanggal 21 Maret 1992. Fakta yuridis yang dimaksud adalah adanya kenyataan bahwa selama ini telah terjadi kekeliruan konsepsi terutama di tingkat elite pengambilan keputusan dalam memahami hakekat benda cagar budaya dan situs.

Contoh kongkritnya terdapat Lampiran Keputusan Direktur Jenderal Departemen Pendidikan dan Kebudayaan Nomor 0248/F1.IV/J.93 tentang Petunjuk Pelaksanaan Tata Cara Pendaftaran Benda Cagar Budaya. Dimana dalam salah satu blanko-nya berjudul Berita Acara Pemeriksaan Benda Tidak Bergerak, namun isi yang tercantum di dalamnya adalah mengenai situs, dengan redaksi yang berbunyi Nomor Urut Situs dan Nama Situs. Padahal kita tahu bahwa secara teoritis maupun yuridis hakekat benda cagar budaya tidak bergerak jelas tidak sama dengan hakekat situs.

Agar kekeliruan pemahaman ini tidak berlarui-larut, tidak ada salahnya kita mencoba untuk membedah peta permasalahan benda cagar budaya dan situs berdasarkan sebuah tinjauan yuridis. Sebelum membahas hakekat benda cagar budaya dan situs berdasarkan ketentuan hukum yang berlaku pada saat sekarang, tidak ada salahnya jika kita mencari bandingan pemahaman berdasarkan ketentuan hukum yang pernah berlaku di negeri ini.

Sebelum tanggal 21 Maret 1992 peraturan perundangan yang mengatur tentang benda cagar budaya dan situs adalah Monumenten Ordonantie Staatsblad Nomor 238 Tahun 1931 (MO). Namun istilah yang digunakan dalam MO bukan benda cagar budaya tetapi monumen atau dalam istilah sehari-hari adalah benda peninggalan sejarah dan purbakala dan situs. Sementara peraturan penundangan yang saat ini berlaku yaitu Undang-undang Republik Indonesia Nomor 5 Tahun 1992 menggunakan istilah benda cagar budaya dan situs.

Permasalahannya menurut Undang-undang Republik Indonesia Nomor 5 Tahun 1992, hakekat benda cagar budaya tidak sama dengan monumen atau benda peninggalan sejarah dan purbakala. Dan hakekat benda cagar budaya tidak bergerak juga sama dengan hakekat situs.

Untuk membuktikan pendapat ini perlu dikemukakan beberapa ketentuan dalam Undang-undang Republik Indonesia Nomor 5 Tahun 1992 pada uraian berikut ini. 
Pertama, alinea keempat Penjelasan atas Undang-undang Republik Indonesia Nomor 5 Tahun 1992 menyatakan : "... Tidak semua benda peninggalan sejarah mempunyai makna sebagai benda cagar budaya ...."

Kedua. pasal 1 Undang-undang Republik Indonesia Nomor 5 Tahun 1992 menyatakan :

1. Benda cagar budaya adalah :

a. benda buatan manusia, bergerak atau tidak bergerak yang berupa kesatuan atau kelompok, atau bagian-bagiannya atau sisa-sisanya. yang berumur sekurang-kurangnya 50 (lima puluh) tahun, atau mewakili masa gaya yang khas dan mewakili masa gaya sekurang-kurangnya 50 (lima puluh) tahun. serta dianggap mempunyai nilai penting bagi sejarah, ilmu pengetahuan dan kebudayaan.

b. benda alam yang dianggap mempunyai nilai penting bagi sejarah, ilmu pengetahuan, dan kebudayaan.

2. Situs adalah lokasi yang mengandung atau diduga mengandung benda cagar budaya termasuk lingkungannya yang diperlukan bagi mengamanannya.

Ketiga, pasal 13 ayat (4) Peraturan Pemerintah Republik Indonesia Nomor 10 Tahun 1993, menyatakan :

"Untuk menentukan temuan tersebut sebagai benda cagar budaya atau situs, dilakukan penelitian".

Pasal 10 ayat (4) Undang-undang Republik Indonesia Nomor 5 Tahun 1992, menyatakan :

"Berdasarkan hasil penelitian sebagaimana dimaksudkan dalam ayat (2). Pemerintah menentukan benda tersebut sebagai benda cagar budaya atau bukan benda cagar budaya, dan menetapkan :

a. pemilikan oleh Negara dengan pemberian imbalan yang wajar kepada penemu;

b. pemilikan sebagian dari benda cagar budaya oleh penemu berdasarkan ketentuan Pasal 6 ayat (2) huruf b;

c. penyerahan kembali kepada penemu, apabila terbukti benda tersebut bukan sebagai benda cagar budaya atau bukan sebagai benda berharga yang tidak diketahui pemiliknya;

d. pemilikan, penguasaan, dan pemanfaatannya sesuai dengan ketentuan peraturan perundangan yang berlaku, apabila benda tersebut ternyata merupakan benda berharga yang tidak diketahui pemiliknya.

Pasal 11 Undang-undang Republik Indonesia Nomor 5 Tahun 1992, menyatakan :

"Pemerintah menetapkan lokasi penemuan benda cagar budaya atau benda yang diduga sebagai benda cagar budaya sebagaimana dimaksud dalam Pasal 10 ayat (1) sebagai situs dengan menetapkan batas-batasnya”.

Pasal 6 ayat (1) Peraturan Pemerintah Republik Indoensia Nomor 10 Tahun 1993. menyatakan : 
"Setiap orang yang memiliki benda cagar budaya wajib mendaftarkannya".

Keputusan Direktur Jenderal Kebudayaan Departemen Pendidikan dan Kebudayaan Nomor 0248/F1.IV/J.93, menyatakan :

"Direktorat Perlindungan dan Pembinaan Peninggalan Sejarah dan Purbakala memproses berkas-berkas pendaftaran yang diterima guna menetapkan/mengesahkan benda yang didaftar sebagai benda cagar budaya. Selanjutnya, dimasukkan ke dalam daftar induk benda cagar budaya dan diterbitkan surat pengesahannya".

Dari beberapa ketentuan yang telah dikemukakan di atas bisa diambil suatu kesimpulan bahwa :

1. Tidak semua benda peninggalan sejarah dan purbakala mempunyai makna sebagai benda cagar budaya.

2. Untuk disebut sebagai benda cagar budaya dan situs harus ada penetapan hukum yang menyatakannya demikian. Dimana sebelum dilakukan penetapan hukum perlu dilakukan penelitian terlebih dahulu untuk menentukan suatu benda sebagai benda cagar budaya dan suatu lokasi sebagai situs.

3. Hakekat benda cagar budaya tidak bergerak tidak sama dengan situs.

Namun jika kita ingin menelaah lebih lanjut persoalan benda cagar budaya dan situs, maka akan muncul sejumlah pertanyaan yang tidak mungkin terjawab berdasarkan ketentuan hukum yang berlaku saat ini. Contohnya pasal 1 Undang-undang tersebut di antaranya :

1) Berumur sekurang-kurangnya $S 0$ (lima puluh) tahun. Permasalahannya; usia 50 (lima puluh) tahun itu dihitung sejak kapan. Sejak Undang-undang Republik Indonesia Nomor 5 Tahum 1992 diundangkan pada tanggal 21 Maret 1992, ataukah sejak benda tersebut ditemukan oleh penemunya, ataukah sejak benda tersebut dilakukan penilaian untuk ditetapkan sebagai benda cagar budaya. Ketidaktegasan bunyi ketentuan undang-undang demikian bisa menimbulkan permasalahan jika diterapkan terhadap kasus kongkrit, khususnya jika terjadi tindak pidana terhadap benda cagar budaya.

2) Nilai penting bagi sejarah, ilmu pengetahuan dan kebudayaan. Permasalahannya; di sini sudah ada nilai sejarah. mengapa harus ada nilai penting bagi ilmu pengetahuan. Bukankah nilai penting bagi ilmu pengetahuan itu sudah termasuk di dalamnya nilai penting bagi sejarah.

Mungkin bisa saja untuk mengatasi hal ini diajukan argumentasi bahwa sejarah itu bisa bermakna sebagai peristiwa dan bisa juga bermakna sebagai ilmu pengetahuan. Namun permasalahannya, argumentasi ini tidak tersurat dalam peraturan perundangan yang ada. sementara Undang-undang Republik Indonesia Nomor 5 Tahun 1992 termasuk kategori hukum pidana tidak diperkenankan adanya sembarang penafsiran karena aturan hukum pidana terikat pada asas 
legalitas sebagaimana bunyi ketentuan pasal 1 ayat (1) Kitab Undang-undang Hukum Pidana.

Pasal 1 ayat (1) Kitab Undang-undang Hukum Pidana. menyatakan :

-Tiada suatu perbuatan dapat dipidanakan kecuali atas kekuatan aturan pidana dalam perundang-undangan yang telah ada, sebelum perbuatan dilakukan”

3) Pengertian situs yang menyatakan : Situs adalah lokasi yang mengandung atau diduga mengandung benda cagar budaya. Permasalahannya; di Indonesia ada lokasi yang sama sekali tidak mengandung benda cagar budaya tetapi disebut sebagai situs, karena di lokasi tersebut pernah terjadi peristiwa bersejarah yang sangat besar perannya bagi perjalanan sejarah bangsa, sehingga lokasinya layak ditetapkan sebagai situs.

Menghadapi berbagai persoalan tersebut di atas tidak ada salahnya jika dipikirkan untuk meninjau kembali berbagai ketentuan di dalam Undang-undang Republik Indonesia Nomor 5 Tahun 1992 beserta peraturan pelaksanaannya, mengingat kelemahan yang ada tidak hanya menyangkut masalah hakekat benda cagar budaya dan situs, tetapi beberapa ketentuan yang lain. terutama jika diterapkan terhadap kasus kongkrit saat terjadi tindak pidana juga bisa menimbulkan permasalahan. 


\section{KEPUSTAKAAN}

Bambang Poemomo, Prof.Dr.SH., 1983, Asas-asas Hukum Pidana, Ghalia Indonesia-Jakarta.

Moeljatno, Prof.Dr.SH., 1978, Kitab Undang-undang Hukum Pidana.

Soesilo, R., Kitab Undang-undang Hukum Pidana Serta Komentarkomentarnya Lengkap Pasal Demi Pasal, Politeia-Bogor.

Subekti, Prof. dan Tjitro Soedibio, 1973, Kamus Hukum, Pradnya Paramita-Jakarta.

Sudikno Mertokusumo, Prof.Dr.SH., 1986, Mengenal Hukum Suatu Pengantar, Liberty-Yogyakarta.

-------, Undang-undang Republik Indonesia Nomor 5 Tahun 1992 tentang Benda Cagar Budaya.

--------, Peraturan Pemerintah Republik Indonesia Nomor 10 Tahun 1993 tentang Pelaksanaan Undang-undang Republik Indonesia Nomor 5 Tahun 1992.

-------, Keputusan Menteri Pendidikan dan Kebudayaan Republik Indonesia Nomor 087/P/1993 tentang Pendaftaran Benda Cagar Budaya.

-------, Keputusan Direktur Jenderal Kebudayaan Departemen Pendidikan dan Kebudayaan Nomor 0248/F1.IV/J.93 tentang Petunjuk Pelaksanaan Tata Cara Pendaftaran Benda Cagar Budaya.

-------, Keputusan Menteri Pendidikan dan Kebudayaan Republik Indonesia Nomor 064/U/1995 tentang Penetapan Benda Cagar Budaya dan/atau Situs. 